\title{
Cytogenetic markers as diagnoses in the identification of the hybrid between Piauçu (Leporinus macrocephalus) and Piapara (Leporinus elongatus)
}

\author{
Fábio Porto-Foresti ${ }^{1}$, Diogo Teruo Hashimoto ${ }^{1}$, Anderson Luis Alves ${ }^{2}$, Rodrigo Braz Castilho Almeida ${ }^{3}$, \\ José Augusto Senhorini ${ }^{4}$, Jehud Bortolozzi ${ }^{1}$ and Fausto Foresti ${ }^{3}$ \\ ${ }^{I}$ Departamento de Ciências Biológicas, Faculdade de Ciências, Universidade Estadual Paulista, \\ Bauru, SP, Brazil. \\ ${ }^{2}$ Departamento de Parasitologia, Instituto de Biologia, Universidade Estadual de Campinas, \\ Campinas, SP, Brazil. \\ ${ }^{3}$ Departamento de Morfologia, Instituto de Biociências, Universidade Estadual Paulista, \\ Botucatu, SP, Brazil. \\ ${ }^{4}$ Centro de Pesquisa e Gestão de Recursos Pesqueiros Continentais, \\ Instituto Brasileiro do Meio Ambiente e dos Recursos Naturais Renováveis, Pirassununga, SP, Brazil.
}

\begin{abstract}
The genetic monitoring of interspecific hybrids involves the application of methodologies able to provide an easy and indubitable genetic characterization of both parental and hybrid individuals. In the present work, cytogenetic techniques were used to identify a hybrid lineage of "Piaupara" in order to caracterize them in relation to the parental species, Leporinus macrocephalus (piauçu) and L. elongatus (piapara). The cytogenetic analysis revealed that $L$. macrocephalus presented $2 \mathrm{n}=54$ chromosomes and a nucleolar organizer regions (NOR) at the telomere of the long arm of the submetacentric chromosome pair 2 . Analysis of constitutive heterochromatin (C-banding) revealed a conspicuous block at the pericentromeric region on the long arm of a submetacentric chromosome pair. L. elongatus presented the same diploid number, $2 n=54$, and a karyotypic formula similar to that of $L$. macrocephalus. The NORs were also at the telomere of the long arm of the submetacentric pair 2 , which was morphologically different from that of $L$. macrocephalus. Heterochromatic blocks were observed at both telomeres of a submetacentric chromosome pair. The hybrid "Piaupara" presented the same diploid number $(2 n=54)$ and karyotypic formula as the parental species and there were no visible differences between parental and hybrid individuals. Differently from the Giemsa staining, NOR- and C-banding analysis showed marked differences which allowed the identification of the hybrids by the different morphology and/or size of the chromosomes carrying the NORs and patterns of heterochromatin distribution in their chromosomes. Such genetic studies are important for fish culture since they can provide tools for monitoring natural and artificial hybridization. They are also useful in biological conservation programmes and in the proper management of natural and reared fish stocks.
\end{abstract}

Key words: interspecific hybrid, fish culture, fish cytogenetics.

Received: January 26, 2007; Accepted: May 17, 2007.

\section{Introduction}

Biological sciences and, particularly, biotechnological studies have played a major role on the development of fish culture over the last decades. The improvement of current methodologies and its application in studies of fish biology and genetics are necessary to develop a better genetic management of both captive stocks and natural populations (Porto-Foresti and Foresti, 2004).

Send correspondence to F. Porto-Foresti. Departamento de Ciências Biológicas, Faculdade de Ciências, Universidade Estadual Paulista, 17033-360 Bauru, SP, Brazil. E-mail: fpforesti@fc.unesp.br.
Interspecific hybridization focused on productivity increase and formation of sterile lineages represents one of the main classic methods of genetic manipulation applied in fish farms. Most of natural fish hybrids are found in continental waters, where the frequency of hybridization and speciation is remarkably higher than that found in marine species, in which hybrids are generally rare (Hubbs, 1955).

The use of artificial hybridization in fish was initiated about 30 years ago in Brazil by the Departamento de Obras Contra a Seca (DNOCS) and involved different species of tilapias (Toledo-Filho et al., 1998). Nowadays, it involves a large number of interspecific crosses among Neotropical 
fish species (Table 1). In this way, the widespread production of interspecific hybrid fishes justifies their effective characterization and the elaboration of monitoring programmes at the production level.

The expressive results obtained with the use of interspecific hybridization techniques in fish need to be carefully interpreted in face of the potential biological risks that hybrids pose to the environment. If fertile, they can genetically contaminate both natural and reared parental stocks (Ryman and Utter, 1987). Otherwise, in natural habitats, they may compete in different ways with parental lineages (Toledo-Filho et al., 1998). Therefore, the genetic identification, characterization and monitoring of hybrids produced by fish breeding farms may provide important information which could be used in hybridization programmes applied to fish culture.

Currently, interspecific hybrid individuals between the species Piauçu (Leporinus macrocephalus) and Piapara (L. elongatus) are being produced in Brazilian fish cultures. The parental species belong to the family Anostomidae, which comprises twelve identified genera and represents an important freshwater fish group widespread throughout the Neotropical region (Géry, 1977). The most representative genera of this family are Leporinus (87 species) and Schizodon (14 species) (Garavello and Britski, 2003), and in the Leporinus group many species constitute important fishery resource to specific communities, such as $L$. macrocephalus, L. elongatus and L. obtusidens.

Although the presence of 54 chromosomes remains constant within the species of the family Anostomidae (Galetti Jr. et al., 1981a), interesting chromosome rearrangements seem to have occurred in this group. Galetti Jr. et al. (1991b) reported perceptible C-banding patterns differences in chromosomes of representatives of the family Anostomidae and, furthermore, Galetti Jr. et al. (1984) demonstrated that the nucleolus organizer regions (NORs) are located on different chromosomes or at distinct chromosome positions. These characteristics can be used as a tool for unambiguous species identification in this family.

Besides the occurrence of normal homomorphic karyotypes in some Leporinus species, the occurrence of a ZZ/ZW sex chromosomes system was also observed (Galetti Jr. et al., 1981b; Galetti Jr. and Foresti, 1986, 1987; Galetti Jr. et al., 1995; Molina and Galetti Jr., 2006). It involved a pair of large meta- and submetacentric chromosomes equivalent in size to the second pair, with the smaller metacentric chromosome corresponding to the $\mathrm{Z}$ and the submetacentric chromosome corresponding to the $\mathrm{W}$ chromosome (Galetti Jr. et al., 1981b; Galetti Jr. and Foresti, 1987).

As the production of interspecific hybrids is currently a common practice among fish breeders, the major goal of the present work was to characterize and differentiate parental species of Leporinus and their artificial interspecific hybrid. We aimed at providing a better understanding on the dynamics of the interspecific hybridization processes in fish, at supporting projects on fish hybridization developed by farmers, and at establishing guidelines for biological conservation programmes involving these species.

\section{Material and Methods}

From the parental lines, 19 specimens of Piauçu (Leporinus macrocephalus) and 20 individuals of Piapara (Leporinus elongatus) were cytogenetically analyzed.

Table 1 - A list of fish species and crosses that produce hybrids identified through the parental species.

\begin{tabular}{|c|c|c|}
\hline \multicolumn{2}{|l|}{ Parental generation } & \multirow[t]{2}{*}{ Hybrid } \\
\hline Parental female & Parental male & \\
\hline Tambaqui - Colossoma macropomum & Pacu - Piaractus mesopotamicus & "Tambacu" \\
\hline Pacu - Piaractus mesopotamicus & Tambaqui - Colossoma macropomum & "Paqui" \\
\hline Tambaqui - Colossoma macropomum & Pirapitinga - Piaractus brachypomus & "Tambatinga" \\
\hline Pirapitinga - Piaractus brachypomus & Tambaqui - Colossoma macropomum & "Pirambaqui" \\
\hline Pacu - Piaractus mesopotamicus & Pirapitinga - Piaractus brachypomus & "Patinga" ou "Papi" \\
\hline Pirapitinga - Piaractus brachypomus & Pacu - Piaractus mesopotamicus & "Pirapicu” \\
\hline Piauçu - Leporinus macrocephalus & Piapara - Leporinus elongatus & "Piaupara" \\
\hline Piapara - Leporinus elongatus & Piauçu - Leporinus macrocephalus & "Piapaçu", \\
\hline Pintado - Pseudoplatystoma corruscans & Cachara - Pseudoplatystoma fasciatum & "Pintachara" \\
\hline Cachara - Pseudoplatystoma fasciatum & Pintado - Pseudoplatystoma corruscans & "Cachapinta" \\
\hline Pintado - Pseudoplatystoma corruscans & Jurupoca - Hemiosorubim platyrhynchos & "Pintajuru” \\
\hline Pintado - Pseudoplatystoma corruscans & Pirarara - Phractocephalus hemioliopterus & "Pintapira" \\
\hline Cachara - Pseudoplatystoma fasciatum & Pirarara - Phractocephalus hemioliopterus & "Cachapira" \\
\hline Pintado - Pseudoplatystoma corruscans & Jandiá - Leiarius marmoratus & "Pintadiá" \\
\hline Jandiá - Leiarius marmoratus & Pintado - Pseudoplatystoma corruscans & "Janditado" \\
\hline
\end{tabular}


Crosses performed between these species resulted in the production of the interspecific hybrid "Piaupara" - the lineage obtained by using females of Piauçu and males of Piapara. The cytogenetic analysis in hybrids comprised 21 specimens of "Piaupara". All the specimens analyzed were obtained from the stock belonging to the Kabeya Aquaculture, Penápolis (SP), Brazil and were identified and deposited in the fish collection of the Laboratory of Fish Genetics, UNESP, Bauru (SP), Brazil.

Chromosome preparations were obtained from gill and kidney tissues using the technique described by Foresti et al. (1981). Silver staining of the nucleolus organizer regions followed the technique of Howell and Black (1980) and C-banding was performed according to Sumner (1972). Chromosome morphology was determined on the basis of arm ratio as proposed by Levan et al. (1964) and the chromosomes were classified as metacentric (M), submetacentric (SM), subtelocentric (ST) and acrocentric (A).

\section{Results and Discussion}

The study of interspecific hybrids depended on the cytogenetic identification of the parental species Piauçu (Leporinus macrocephalus) and Piapara (L. elongatus), thus chromosome preparations both species were obtained.

\section{Cytogenetic identification of Piauçu ( $L$. macrocephalus) and Piapara (L. elongatus)}

Nineteen specimens of L. macrocephalus (Piauçu) (five females and 14 males) were analyzed. They presented a diploid number of $2 n=54$ and their karyotype was similar to that described by Galetti Jr. and Foresti (1987). The fundamental number (FN) in this species was 108 and the chromosome formula comprised meta- and submetacentric chromosomes and a ZZ/ZW sex chromosome pair (Figure 1a).

Twenty specimens of L. elongatus (Piapara) (eight females and 12 males) were analyzed. The specimens showed $2 \mathrm{n}=54$, with a karyotype composed of meta- and submetacentric chromosomes and a fundamental number (FN) equal to 108 , confirming previous reports by Galetti Jr. and Foresti (1986), Koehler et al. (1997) and Molina et al. (1998). This species also presented the ZZ/ZW sex chromosome system (Figure 1b).

According to Vari (1983), the family Anostomidae shares the same phylogenetic unit with Curimatidae, Prochilodontidae and Chilodontidae. Karyotypic studies carried out in representatives of the Anostomidae family showed a basic karyotype composed of 54 mostly metaand submetacentric chromosomes (Galetti Jr. et al., 1981a), similar to the karyotypes of $L$. macrocephalus and $L$. elongatus herein studied.

Furthermore, the cytogenetic analysis confirmed the occurrence of a chromosomal heteromorphism related to sex in both species (Figures 1a and 1b) previously observed in some Leporinus species (Galetti Jr. et al., 1981b; Galetti
Jr. and Foresti, 1986, 1987; Galetti Jr. et al., 1995; Molina et al., 1998; Molina and Galetti Jr., 2006).

Analysis in three genera of the family Anostomidae (Leporinus, Leporellus and Schizodon) demonstrated that, superficially, they have a great karyotypic similarity (Galetti Jr. et al., 1981a). Further cytogenetic analysis applying silver nitrate staining of the nucleolus organizer regions (NORs) were informative enough to characterize some species in this group. Although all of them presented a single NOR-bearing pair, the NORs were at different chromosome positions. The differences might be related to chromosome rearrangements as translocations and/or inversions, thus representing cytogenetic markers for these species (Galetti Jr. et al., 1984).

Silver nitrate staining on chromosome preparations of L. macrocephalus and L. elongatus revealed the presence of a single chromosome pair bearing ribosomal cistrons in both species. The NORs were located at a terminal position on the long arm of a submetacentric chromosome (pair 2) in both species (Figures 1a and $1 \mathrm{~b}$ - inbox). However, as the NOR-bearing chromosomes in each species have different sizes and/or morphologies, they can be useful cytological markers for the identification of interspecific hybrids between these species.

C-banding of $L$. macrocephalus and $L$. elongatus chromosomes revealed the presence of heterochromatic blocks over centromeric and pericentromeric regions of some chromosomes in both species. In L. macrocephalus, conspicuous interstitial blocks were present in the pericentromeric region at the long arms of the submetacentric chromosomes of the third pair (Figure 2a - inbox). In $L$. elongatus, additional telomeric staining was detected on both arms of the medium-sized submetacentric chromosomes of the second pair (Figure $2 b$ - inbox). The telomeric heterochromatic blocks were associated to the nucleolus organizer regions, in accordance with previous data for some other species of the genus (Koehler et al., 1997; Molina et al., 1998).

The heteromorphic sex chromosomes of both species followed the morphological and structural patterns of $Z$ and W chromosomes previously reported in Leporinus species, with heterochromatic regions occupying nearly entirely the long arms of $\mathrm{W}$ chromosomes and the final portion of the long arms of $\mathrm{Z}$ chromosomes (Galetti Jr. et al., 1981b; Koehler et al., 1997; Molina et al., 1998).

Interspecific differences related to constitutive heterochromatin evidenced by $\mathrm{C}$-banding patterns have already been described in some Leporinus species. While some of them presented a low amount of heterochromatin, such as L. piau, others like L. amblyrhyncus and L. taeniatus present heterochromatic blocks distributed over centromeric and telomeric regions. Furthermore, in L. striatus, interstitial blocks of heterochromatin were also reported (Galetti Jr. et al., 1991a). The different patterns of heterochromatin described in some species of this group suggest that some 

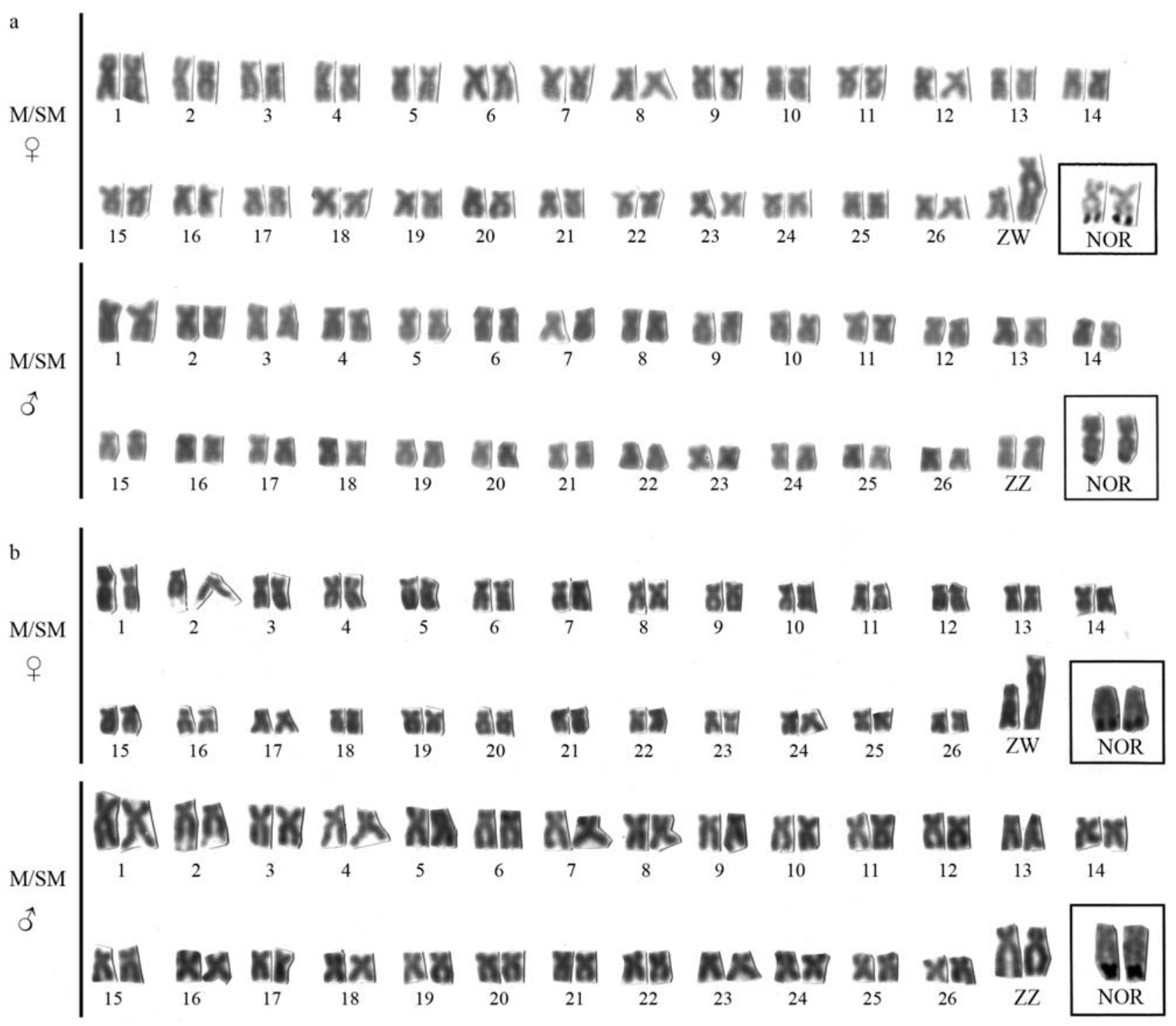

Figure 1 - Giemsa-stained karyotype (female and male) of Leporinus macrocephalus (Piauçu) (a) and Leporinus elongatus (Piapara) (b). Inbox, the NOR-bearing chromosome pair 2.

rearrangements might have played a controlling role on the structural karyotypic changes (Galetti Jr. et al., 1991a). Other species, with reduced amounts of heterochromatin, possibly presented a differentiation pattern associated with qualitative and quantitative changes in their heterochromatic segments (Galetti Jr. et al., 1991b).

C-banding and NORs distribution allowed the characterization of chromosome markers in both parental species, which constitute important tools in the identification of the parental lineages and hybrids.

\section{Cytogenetic identification of the hybrid "Piaupara"}

Twenty-one specimens of the hybrid "Piaupara" obtained through crosses between Piauçu females and Piapara males were analyzed. The results revealed a diploid number of $2 n=54$ in all individuals, with a fundamental number of 108 and a chromosome formula composed of meta- and submetacentric chromosomes, besides ZZ/ZW sex chromosomes (Figure 3).

Due to the morphological similarity between the karyotypes of the parental species, the "Piaupara" hybrid presented the same diploid number and karyotypic formula described in L. macrocephalus (Piauçu) and L. elongatus (Piapara), thus preventing its identification. There are well documented cases of hybrids and their parental species sharing an identical karyotype, such as in hybrids between pacu (Piaractus mesopotamicus) and tambaqui (Colossoma macropomum), which have $2 \mathrm{n}=54$ and karyotypes composed of 20 metacentric and 34 submetacentric chromosomes (Almeida-Toledo et al., 1987). A similar situation has been reported in natural hybrids resulting from crosses between Cichla monoculus and Cichla temensis by Brinn et al. (2004), who detected $2 \mathrm{n}=48$ acrocentric chromosomes in hybrids and parental specimens. 

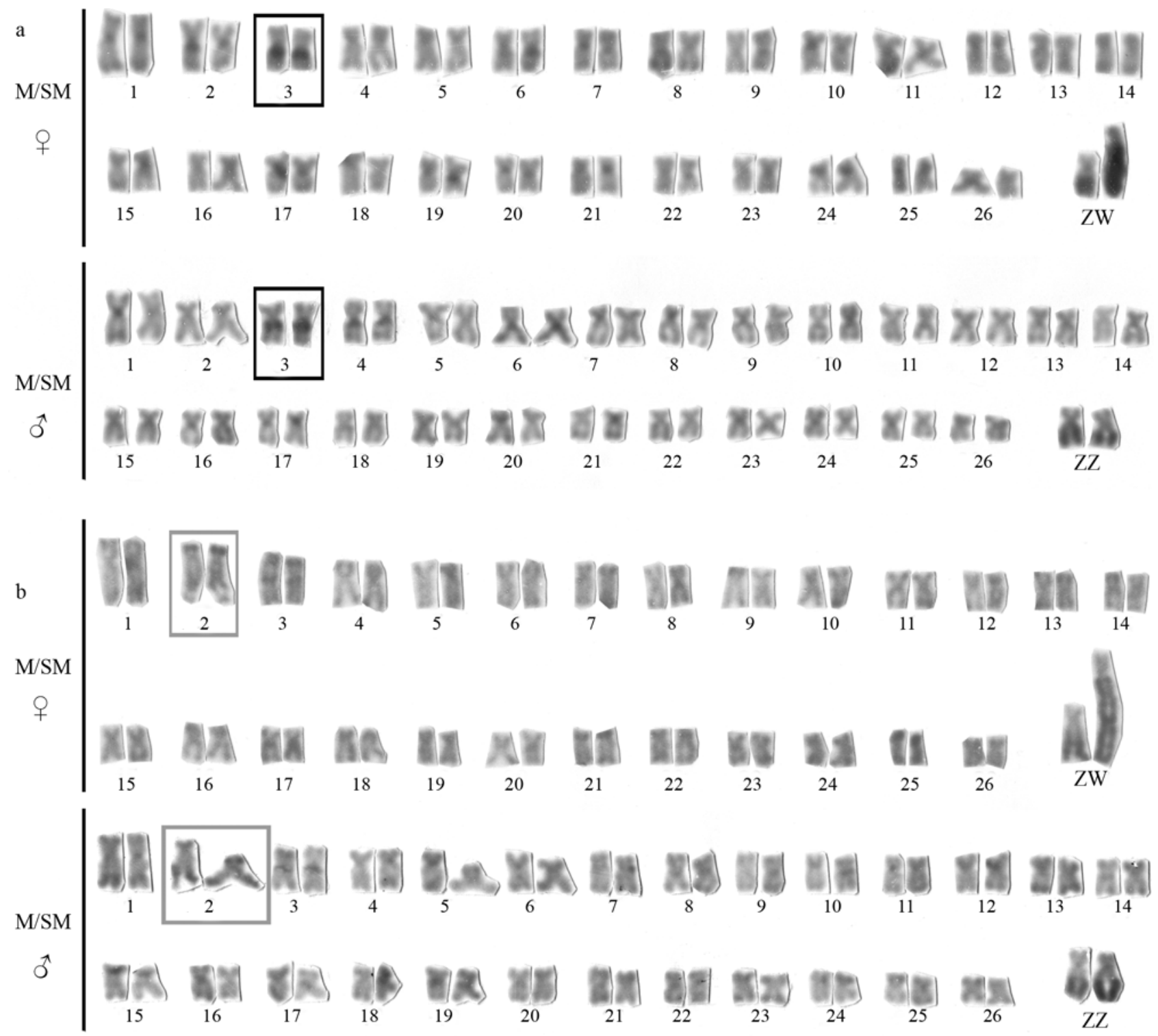

Figure 2 - C-banded karyotypes (female and male) of Leporinus macrocephalus (Piauçu) (a) and Leporinus elongatus (Piapara) (b). The marker chromosomes are shown in detail (inbox).
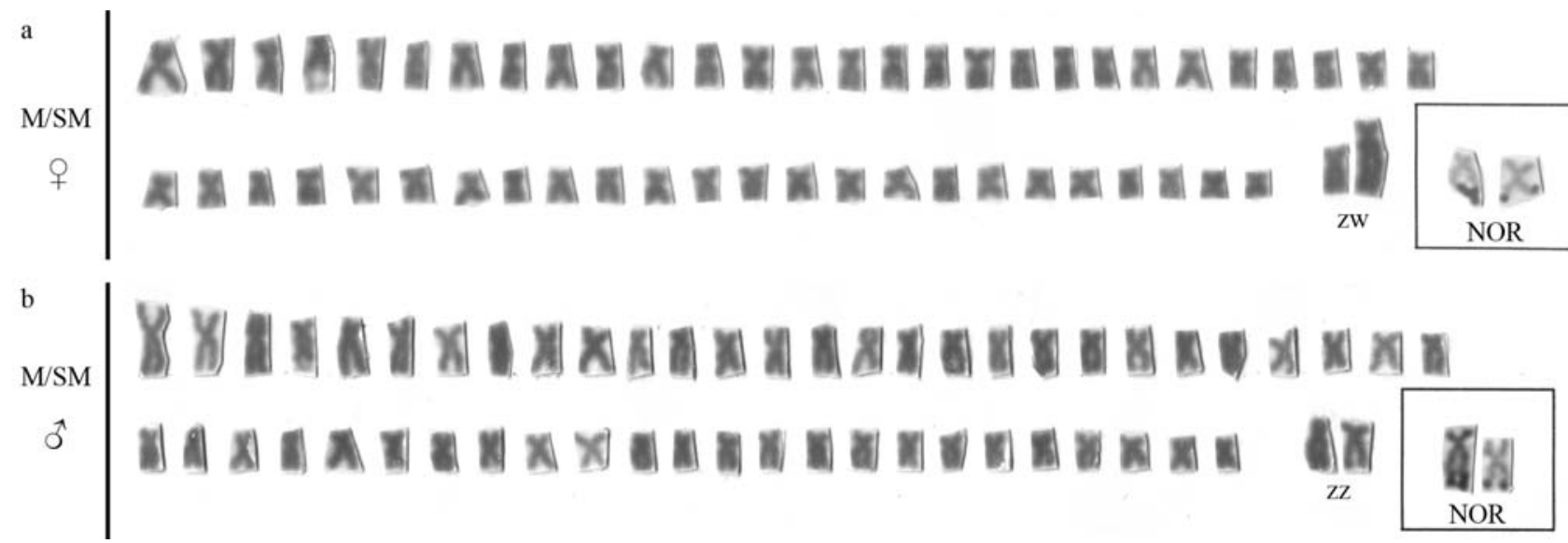

Figure 3 - Karyotype of female (a) and male (b) individuals of the interspecific hybrid "Piaupara" $(2 n=54)$. Inbox, the NOR-bearing chromosome pair. 
In other cases of interspecific hybridization in fish, the parental species and their interspecific hybrids presented distinct karyotypes. That was the case of a hybridization program involving two species with $2 \mathrm{n}=54$ but distinct karyotypic formulas. Tambaqui (Colossoma macropoтиm) females were crossed with pacu-peva (Mylossoma duriventris) males and the crosses resulted in hybrid individuals with 54 chromosomes, which were identified by an acrocentric marker chromosome inherited from the male parental species (Kossowski et al., 1983).

The cytogenetic analysis carried out in the hybrid "Piaupara" also revealed that the particular ZZ/ZW sex chromosome heteromorphism found in the parental species (Figure 3), is also present in the hybrid individuals and linked to sex determination.

In the hybrid individuals the submetacentric NORbearing chromosomes had different morphologies and were apparently not homologous (Figure 4). After silver nitrate staining the following NORs distribution was observed: $20,21 \%$ of the cells presented the NORs in the chromosomes of a submetacentric pair with different morphologies; $78,42 \%$ of the cells presented a NOR in one chromosome of the pair, identified as a component of the $L$. elongatus karyotype; and $1,37 \%$ of the cells presented the NOR in one chromosome identified as being from $L$. macrocephalus (Table 2 and Figure 5).

This variation in the NORs distribution is due to the fact that the silver nitrate staining detects active NORs, since it stains not the rDNA but rather a set of acidic proteins associated with the process of ribosome production (Howell, 1977; Jordan, 1987). Thus, the difference in activ-

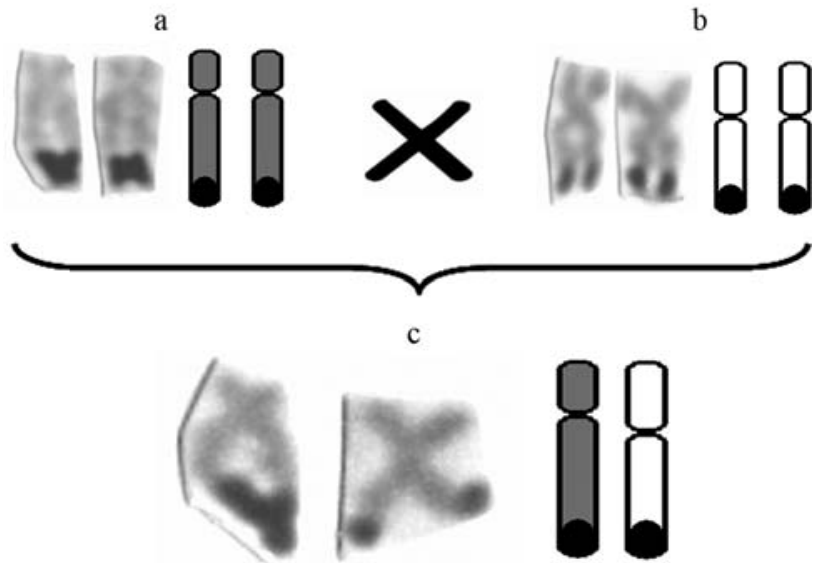

Figure 4 - NOR-bearing chromosomes (silver nitrate staining) in the parental species Leporinus elongatus (a) and L. macrocephalus (b) and NOR-bearing chromosomes in the interspecific hybrid "Piaupara" (c).

ity found in the rDNA sites in the hybrids, which present a frequent activity of the NOR from the L. elongatus NORbearing chromosome, may indicate the occurrence nucleolar dominance. This phenomenon has already been identified in hybrids of cyprinid fishes (Gold et al., 1991) and other organisms, such as in the wheat Aegilops umbellulata (Martini et al., 1982), in Xenopus hybrids (Reeder and Roan, 1984), and in hybrids of Drosophila (Durica and Krider, 1978).

C-banding in "Piaupara" revealed the presence of heterochromatic blocks at centromeric and pericentromeric regions of some chromosomes (Figure 6). Besides that, it showed an evident heterochromatic block near the peri-

Table 2 - Distribution of NOR-bearing chromosomes after silver nitrate staining in the interspecific "Piaupara" hybrids.

\begin{tabular}{|c|c|c|c|}
\hline $\begin{array}{l}\text { Cells with two Ag-NORs in the heteromorphic } \\
\text { submetacentric pair (one chromosome from } L \text {. } \\
\text { elongatus and the other from L. macrocephalus) }\end{array}$ & $\begin{array}{l}\text { Cells with one Ag-NOR in the } L \text {. } \\
\text { elongatus chromosome of the } \\
\text { pair }\end{array}$ & $\begin{array}{l}\text { Cells with one Ag-NOR in the } \\
\text { L. macrocephalus chromo- } \\
\text { some of the pair }\end{array}$ & Total of analyzed cells (\%) \\
\hline $59(20.21 \%)$ & $229(78.42 \%)$ & $4(1.37 \%)$ & $292(100 \%)$ \\
\hline
\end{tabular}
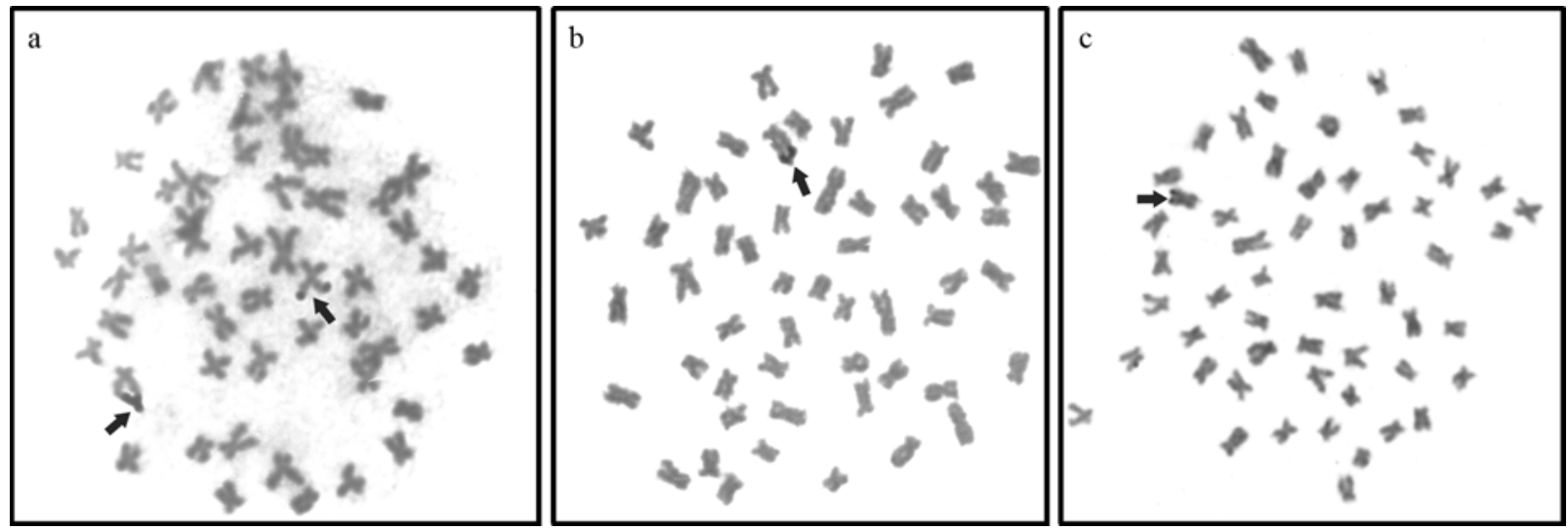

Figure 5 - Metaphases of the interspecific hybrid "Piaupara" (silver nitrate staining). In (a), a heteromorphic submetacentric chromosome pair with one homologue from L. elongatus (arrow) and the other from L. macrocephalus (arrow); in (b), the L. elongatus homologue of the pair (arrows); and in (c), the L. macrocephalus homologue of the heteromorphic pair (arrows). 
a
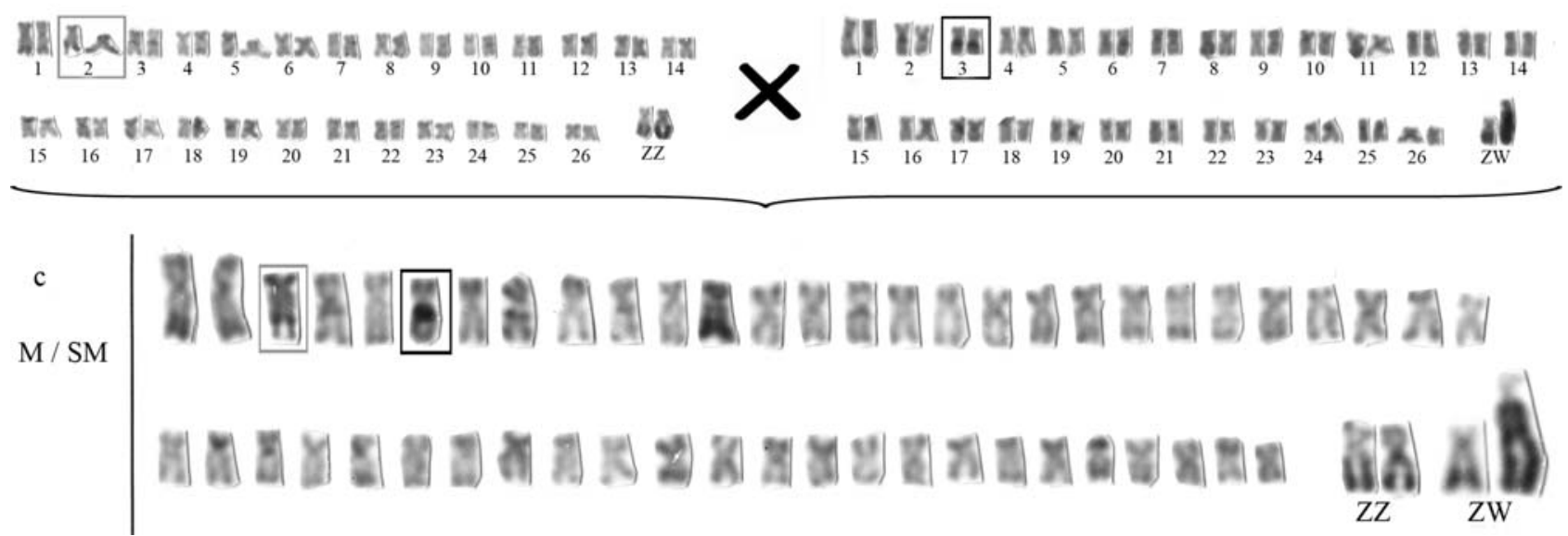

Figure 6 - C-banded karyotypes of the parental species Leporinus elongatus (a) and L. macrocephalus (b) and of the interspecific hybrid "Piaupara" (c). The marker chromosomes from each parental species are shown in detail in the interspecific hybrid.

centromeric region of one chromosome (Figure 6 - inbox), analogous to that described in L. macrocephalus, and subtle staining at telomeric regions in both arms of one chromosome (Figure 6 - inbox), similar to that found in $L$. elongatus. Thus, the typical heterochromatic blocks from each parental species were present in the hybrid "Piaupara" in single chromosomes, demonstrating that chromosome features inherited from both parental species can be identified as specific parental markers in the hybrids.

C-banding also revealed that the hybrid sex chromosomes have the same morphological and structural patterns reported in both parental species, L. macrocephalus and $L$. elongatus, i.e., almost entirely heterochromatic long arms in the $\mathrm{W}$ chromosome and heterochromatin in the final portion of the long arms of $\mathrm{Z}$ chromosomes (Figure 6).

When hybrids and parental individuals present similar karyotypes the use of differential staining techniques and chromosome banding are required to provide distinguishable chromosomal markers. C-banding allowed the precise identification of the parental species and the hybrids obtained from crosses between pacu (Piaractus mesopotamicus) and tambaqui (Colossoma macropomum) (Almeida-Toledo et al., 1987, 1988). C-banding in the cichlid fish species Cichla monoculus and C. temensis and their hybrids revealed a very similar banding pattern distribution hindering the distinction between the parental and the hybrid specimens (Brinn et al., 2004).

In the present work, Ag-NORs and C-banding proved to be informative and allowed the identification of specific chromosome markers of the parental sets in the hybrids. The use of chromomycin $\mathrm{A}_{3}$ and in situ hybridization with the $18 \mathrm{~S}$ probe will allow a better identification of the NORs sites in "Piaupara". It may also lead to a better comprehension of the process of nucleolar dominance that may be occurring in these individuals.
Cytogenetic markers can be very useful for the characterization and differentiation between parental species and artificial or natural interspecific hybrid lineages or individuals. Cytogenetic information can contribute to a better understanding of the dynamics of the interspecific hybridization process in fish, and provide support for hybridization projects and biological conservation programmes.

\section{Acknowledgments}

F.P.F. was supported by a fellowship from Fundação de Amparo à Pesquisa do Estado de São Paulo (FAPESP). This work was supported by grants from Fundação de Amparo à Pesquisa do Estado de São Paulo (FAPESP).

\section{References}

Almeida-Toledo LF, Foresti F, Toledo-Filho SA, Bernardino G, Ferrari VA and Alcantara RCG (1987) Cytogenetic studies in C. mitrei, C. macropomum and their interspecific hybrid. In: Tiews K (ed) Selection, Hybridization and Genetic Engineering in Aquaculture. Berlin Heenemann Verlagsgesellshaft mb II v. 1, pp 189-195.

Almeida-Toledo LF, Foresti F, Ramos SM, Ormanezi R, Carosfeld VJS and Toledo-Filho SA (1988) Estudos citogenéticos de híbridos entre fêmeas de pacu (Piaractus mesopotamicus) e machos de tambaqui (Colossoma macropomum). B Tec CEPTA 1:1-17.

Brinn MNA, Porto JIR and Feldberg E (2004) Karyological evidence for interspecific hybridization between Cichla monoculus and C. temensis (Perciformes, Cichlidae) in the Amazon. Hereditas 141:252-257.

Durica DS and Krider HM (1978) Studies on the ribosomal RNA cistrons in Drosophila hybrids. II. Heterochromatic regions mediating nucleolar dominance. Genetics 89:37-64.

Foresti F, Almeida-Toledo LF and Toledo-Filho SA (1981) Polymorphic nature of nucleolus organizer regions in fishes. Cytogenet Cell Genet 31:137-144. 
Galetti Jr PM and Foresti F (1986) Evolution of the ZZ/ZW system in Leporinus (Pisces, Anostomidae). Cytogenet Cell Genet 43:43-46.

Galetti Jr PM and Foresti F (1987) Two new cases of ZZ/ZW heterogamety in Leporinus (Anostomidae, Characiformes) and their relationships in the phylogeny of the group. Braz $\mathrm{J}$ Genet 10:135-140.

Galetti Jr PM, Foresti F, Bertollo LAC and Moreira-Filho O (1981a) Karyotypic similarity in three genera (Leporinus, Leporellus and Schizodon) of the family Anostomidae (Pisces, Teleostei). Braz J Genet 4:11-15.

Galetti Jr PM, Foresti F, Bertollo LAC and Moreira-Filho O (1981b) Heteromorphic sex chromosomes in three species of the genus Leporinus (Pisces, Anostomidae). Cytogenet Cell Genet 29:138-142.

Galetti Jr PM, Foresti F, Bertollo LAC and Moreira-Filho O (1984) Characterization of eight species of Anostomidae (Cypriniformes) fish on the basis of the nucleolar organizing region. Caryologia 37:401-406.

Galetti Jr PM, Cesar ACG and Venere PC (1991a) Heterochromatin and NORs variability in Leporinus fish (Anostomidae, Characiformes). Caryologia 44:287-292.

Galetti Jr PM, Mestriner CA, Venere PC and Foresti F (1991b) Heterochromatin and karyotype reorganization in fish of the family Anostomidae (Characiformes). Cytogenet Cell Genet 56:116-121.

Galetti Jr PM, Lima NRW and Venere PC (1995) A monophyletic ZW chromosome system in Leporinus (Anostomidae, Characiformes). Cytologia 60:375-382.

Garavello JC and Britski HA (2003) A Family Anostomidae (Headstanders). In: Reis RE, Kullander SO and Ferraris Jr CJ (eds) Check list of the freshwater fishes of South and Central America. EDIPUCRS, Porto Alegre, pp 71-84.

Géry J (1977) Characoids of the World. T.F.H. Publications, Neptune City, $672 \mathrm{pp}$.

Gold JR, Li Y, Schmidt TR and Tave D (1991) Nucleolar dominance in interspecific hybrids of cyprinid fishes. Cytobios 65:139-147.

Howell WM (1977) Visualization of ribosomal gene activity: Silver stains proteins associated with rRNA transcribed from oocyte chromosomes. Chromosoma 62:361-367.

Howell WM and Black DA (1980) Controlled silver-staining of nucleolus organizer regions with a protective colloidal developer: A 1-step method. Experientia 36:1014-1015.

Hubbs CL (1955) Hybridization between fish species in nature. Syst Zool 4:1-20.
Jordan G (1987) At the heart of the nucleolus. Nature 329:489490.

Koehler MR, Dehm D, Guttenbach M, Nanda I, Haaf T, Molina WF, Galetti Jr PM and Schmid M (1997) Cytogenetics of the genus Leporinus (Pisces, Anostomidae). 1. Karyotype analysis, heterochromatin distribution and sex chromosomes. Chromosome Res 5:12-22.

Kossowski Q, Bracamonte NO and Velasco JQ (1983) Cariotipo del hibrido de Colossoma macropomum (hembra) (Cuvier) 1818 Mylossoma duriventris (macho) (Cuvier) 1818 y sus progenitores. Acta Científica Venezolana 34:173-175.

Levan A, Fredga K and Sandbreg AA (1964) Nomenclature for centromeric position on chromosomes. Hereditas 52:201220.

Martini G, O'Dell M and Flavell RB (1982) Partial inactivation of wheat nucleolus organizers by the nucleolus organizer from Aegilops umbellulata. Chromosoma 84:687-700.

Molina WF and Galetti Jr PM (2006) Early replication banding in Leporinus species (Osteichthyes, Characiformes) bearing differentiated sex chromosomes (ZW). Genetica 1:1-15.

Molina WF, Schmid M and Galetti Jr PM (1998) Heterochromatin and sex chromosomes in the Neotropical fish genus Leporinus (Characiformes, Anostomidae). Cytobios 94:141-149.

Porto-Foresti F and Foresti F (2004) Genética e biotecnologia em piscicultura: Usos na produção, manejo e conservação dos estoques de peixes. Tópicos especiais em piscicultura de água doce tropical intensiva. TecArt, São Paulo, pp 195215.

Reeder RH and Roan JG (1984) The mechanism of nucleolar dominance in Xenopus hybrids. Cell 38:39-44.

Ryman N and Utter FM (1987) Population Genetics \& Fishery Management. University of Washington Press, Seattle, $420 \mathrm{pp}$.

Sumner AT (1972) A simple technique for demonstrating centromeric heterochromatin. Exp Cell Res 75:304-306.

Toledo-Filho SA, Almeida-Toledo LF, Foresti F, Calcagnotto D, Fonteles-Santos SBA and Bernardino G (1998) Cadernos de Ictiogenética 4: Programas Genéticos de Seleção, Hibridação e Endocruzamento Aplicados à Piscicultura. Universidade de São Paulo, São Paulo, 56 pp.

Vari RP (1983) Phylogenetic relationships of the families Curimatidae, Prochilodontidae, Anostomidae and Chilodontidae (Pisces, Characiformes). Smithsonian Contributions to Zoology 378:1-60.

Associate Editor: Yatiyo Yonenaga-Yassuda

License information: This is an open-access article distributed under the terms of the Creative Commons Attribution License, which permits unrestricted use, distribution, and reproduction in any medium, provided the original work is properly cited. 